\title{
Thyasira ockelmanni (Mollusca: Bivalvia: Veneroidea), A new species of Thyasiridae from the Norwegian Sea
}

\author{
Rozemarïn Keuning and Christoffer Schander
}

\begin{abstract}
Keuning R and Schander C. 2010. Thyasira ockelmanni (Mollusca: Bivalvia: Veneroidea), A new species of Thyasiridae from the Norwegian Sea. Fauna norvegica 30: 21-24.

A new species of Thyasiridae, Thyasira ockelmanni n.sp. is described from the abyssal depths of the Norwegian Sea. The generic assignment is tentative and possible alternatives are discussed. The new species has some resemblance to Thyasira subovata (Jeffreys, 1881) and Adontorhina similis Barry \& McCormack, 2007, but the posterior outline is rounded and not angulate or truncate as in these species.
\end{abstract}

Keywords: Thyasira, Norwegian Sea, Anatomy, SEM

doi: 10.5324/fn.v30i0.640. Recieved: 2010-07-08. Accepted: 2010-10-26. Published online: 2010-12-21.

Rozemarijn Keuning, Department of Biology, University of Bergen, 5020 Bergen, Norway

Christoffer Schander, Department of Biology, University of Bergen, 5020 Bergen, Norway; GeoBio,

University of Bergen, Allegatén 41, 5007 Bergen, Norway and Uni Miljø, 5020 Bergen, Norway.

Corresponding author: Christoffer Schander

E-mail: Christoffer.Schander@bio.uib.no

\section{INTRODUCTION}

The family Thyasiridae is a group of minute bivalves occurring in a variety of habitats. Several species are known to live in symbiosis with sulphide oxidizing bacteria (e.g. Wood \& Kelly 1989, Distel \&Wood 1992, Dando \& Spiro 1993, Zuschin et al. 2001, Dando et al. 2004 and references therein). Most species have an extensive burrowing behaviour and thereby contribute to oxygenation of the sediments. Some mine reduced sediments for sulphides, making the environment more attractive to sulphide-intolerant benthos (Dufour \& Felbeck 2003). Not much is known about this family in the Norwegian Sea.

Friele \& Grieg (1901) referred to five species of Thyasiridae sampled during the Norwegian Deep Sea Expedition 18761878 , and according to Oliver \& Killeen (2002) sixteen species of Thyasiridae are currently recognized from the North-East Atlantic, but more can be expected. We here describe a new species; Thyasira ockelmanni n.sp. from the Norwegian Sea.

\section{MATERIAL AND METHODS}

Material of the new species was picked out during a workshop in spring 2008 where molluscan material collected by Jon-Arne Sneli and Torleiv Brattegard during more than 30 "Norwegian Sea" cruises mainly in the 1980 's, was worked up.

The microscope photographs were taken with a Leica MZ16A equipped with a Nikon Digital Sight DS-5m camera, and the software ACT-2U. Several images were taken in different phocal planes and assembled using the software Automontage Pro (Synoptics Ltd.). Images processed in Automontage were then imported into Adobe Photoshop CS2 for further adjustment.

SEM images were taken using a Zeiss SUPRA 55VP at the University of Bergen.

The type material is deposited in the Museum of Natural History and Archaeology, Norwegian University of Science and Technology, Trondheim, Norway. 


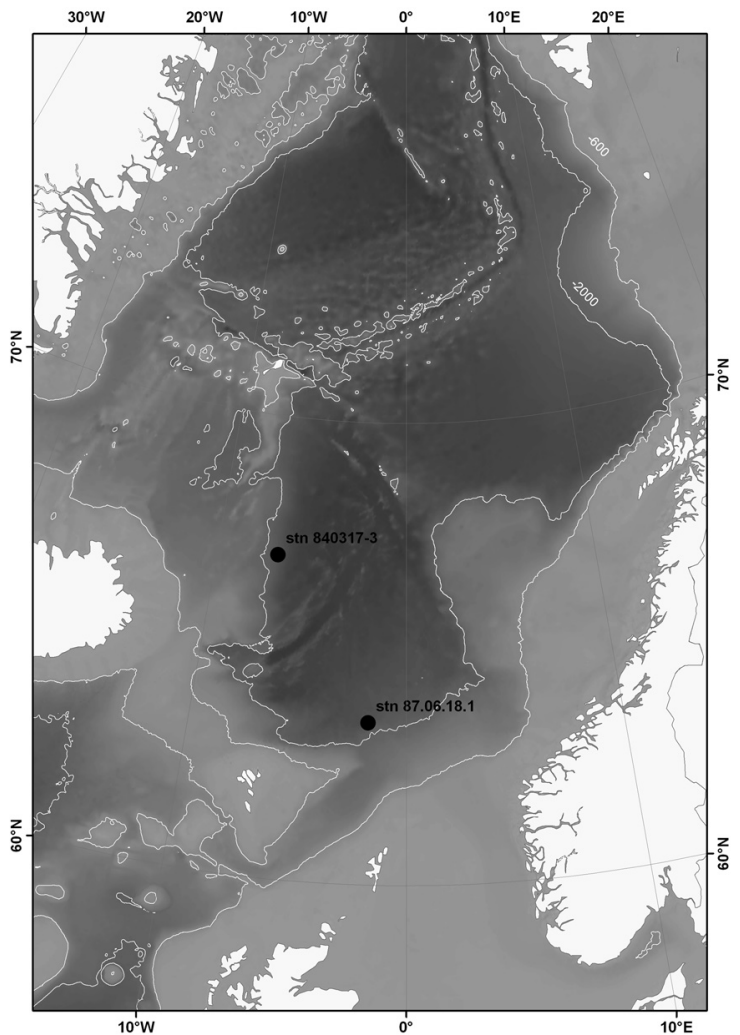

Figure I. Map of the Norwegian Sea with the locations of type material of Thyasira ockelmanni. Base map from General Bathymetric Chart of the Oceans (GEBCO) and ESRI.

\section{Systematics}

Class Bivalvia Linnaeus, 1758

Order Veneroida H. \& A. Adams, 1857

Superfamily Thyasiroidea Dall, 1900

Family Thyasiridae Dall, 1900

\section{Genus Thyasira Lamarck, 1818 ex Leach MS}

Subgenus Mendicula Iredale 1924

Thyasira ockelmanni $\mathrm{n} . \mathrm{sp}$.

\section{Material examined (Fig. 1)}

Holotype: St. R-P 87.06.18.1: $63^{\circ} 01.6 \mathrm{~N}, 06^{\circ} 47.3 \mathrm{~W}$, depth: $2400 \mathrm{~m}$ (VM type-734). Bottom temperature $-0.92^{\circ} \mathrm{C}$.

Paratype: St. 840317-3: $67^{\circ} 01.6$ N, $06^{\circ} 47.3$ W, depth: $2405 \mathrm{~m}$ $-2576 \mathrm{~m}$, detritus sledge 1 specimen (VM type-735). Destroyed during preparation.

\section{Diagnosis}

External characters (Figs. 2 A-D)

Shell small, white, semi-transparent, fragile; maximum length approximately $2 \mathrm{~mm}$. Surface smooth, sculpture of weak concentric lines and growth stops. Ferruginous deposits mostly restricted to anterior margin and posterior area. Outline subequilateral, roundly subovate. Beak slightly posterior to the midline with umbo projecting anteriorly. Shell length greater than shell height. Posterior margin sloping steeply and posterior area rounded. Posterior folds indistinct. Ligament sunken and auricle absent. Ventral and anterior margins broadly rounded. Lunule margin short and sunken; lunule small, slightly excavated.

Hinge plates smooth and devoid of irregular granules. Hinge plate on right valve swollen, projecting ventral and anterior to the beak; a characteristic elongate 'tooth' present anterior to the beak on the left valve. Posterior to beak on left valve, hinge plate narrow and not thickened. Lateral teeth absent.

Internal morphology (Fig. 2 E)

Gills consist of a single demibranch with filaments clearly visible. Anterior adductor muscle somewhat larger and more elongate than posterior adductor muscle.

\section{Remarks}

The holotype was selected from a sample also containing a completely destroyed indeterminable bivalve (VM 61440). The holotype is mounted on a SEM stub.

The species might resemble specimens of Thyasira subovata (Jeffreys, 1881) or Adontorhina similis Barry \& McCormack, 2007, but the posterior outline is rounded and not angulate or truncate as in these species. In addition the gills of Thyasira subovata consist of both inner and outer demibranchs, while the gills of T. ockelmanni $n$.sp. consist of a single demibranch.

\section{Etymology}

This species is named after Kurt W. Ockelmann in recognition of his life-long contribution to mollusc research and especially the bivalve family Thyasiridae.

\section{DISCUSSION}

Several new species of the family Thyasiridae have recently been described from the North Atlantic (Barry \& McCormack 2007) and more are expected to be found in the future. It is a 

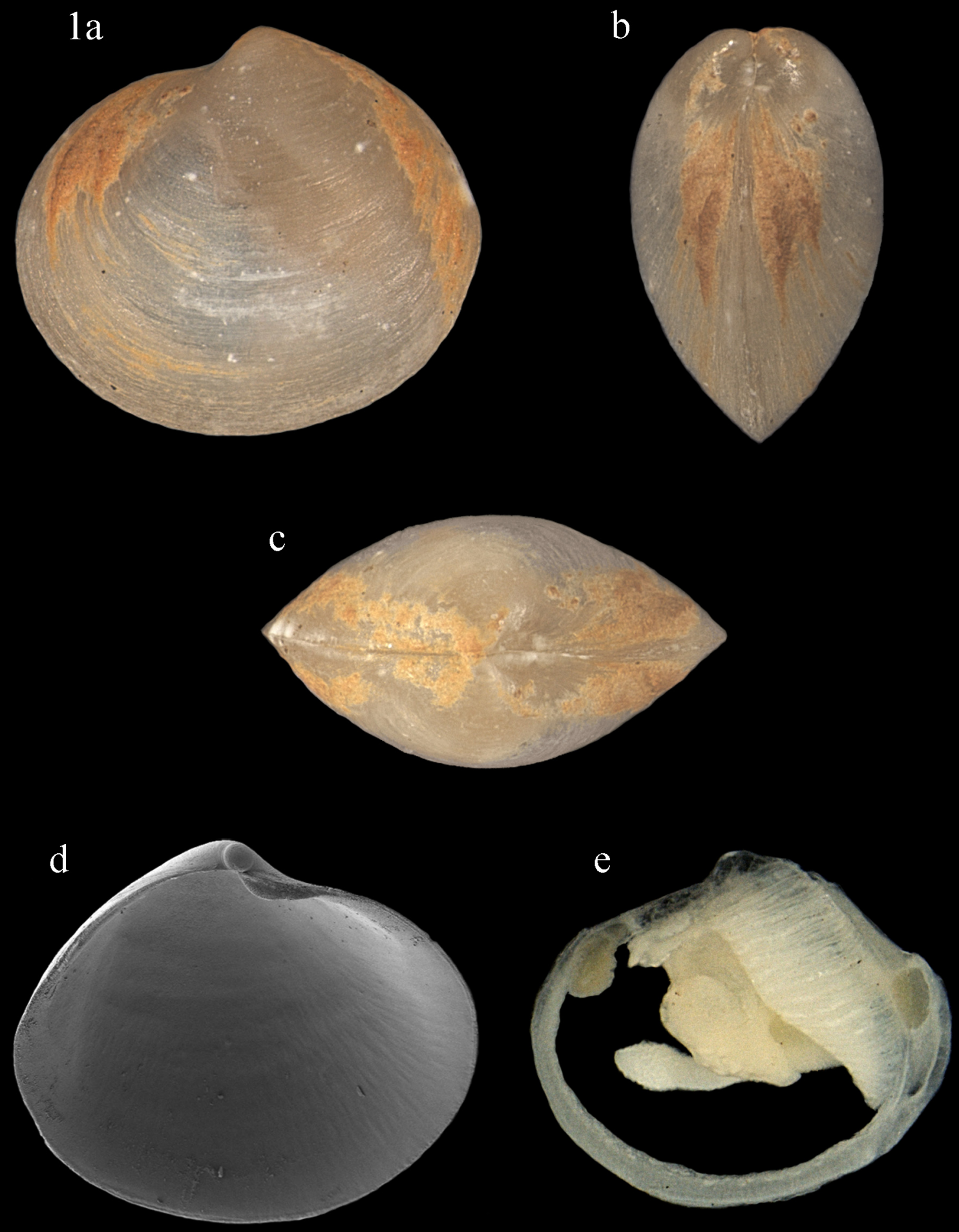

\section{$1 \mathrm{~mm}$}

Figure 2. Thyasira ockelmanni, n. sp. A-C: External morphology of paratype, VM type-735. D: SEM of inside of Holotype, VM type-734. E: Internal anatomy of paratype, VM type-735. Scale bar $1 \mathrm{~mm}$. Photo: Rozemarijn Keuning. 
difficult family to divide in subgenera and its nomenclature is under constant revision as molecular techniques evolve (Taylor et al. 2007). Based solely on morphological characters this species would be best placed in the genus Mendicula, although a strong posterior marginal angle as described in Payne and Allan (1991) is lacking. The inner and outer shell morphology differs to that of the genus Adontorhina with the lack of irregular granules on the hinge, which is characteristic for this genus. Internal morphology could resemble that of the genus Axinulus (Oliver \& Killeen, 2002, plate 3C), but external morphology does not support placement of $T$. ockelmanni $\mathrm{n}$.sp. in this genus.

\section{ACKNOWLEDGEMENTS}

We thank Jon-Arne Sneli, NTNU, Norway for inviting us to the workshop in Trondheim working on the Norwegian Sea material. We thank the Norwegian Academy of Sciences for financing the workshop. Rüdiger Bieler, Field Museum, Chicago, USA is thanked for bibliographical help. Hans Tore Rapp, Univ. Bergen, Norway is thanked for reading and commenting on the manuscript. Comments from two anonymous referees greatly improved the manuscript. This is a publication from the Centre for Geobiology, University of Bergen.

\section{REFERENCES}

Adams H. \& Adams A. 1856. The genera of recent mollusca, arranged according to their organization. Vol. 2. pp. 285-412. London, Van Voorst

Barry P.J. \& McCormack G. P. 2007. Two new species of Adontorhina Berry, 1947 (Bivalvia, Thyasiridae) from Porcupine Bank, off the West coast of Ireland. Zootaxa 1526: $37-49$.

Dall W. H. 1900. Contributions to the Tertiary fauna, with especial reference to the Miocene silex-beds of Tampa and the Pliocene beds of the Caloosahatchie River. Part 5. Teleodesmacea: Solen to Diplodonta. Transactions of the Wagner Free Institute of Science, Philadelphia 3: 949-1218, plates 36-47.

Dando P. R., Southward A. J. \& Southward E. C. 2004. Rates of sediment sulphide oxidation by the bivalve mollusc Thyasira sarsi. Marine Ecology Progress Series 280: 181-187.

Dando P. R. \& Spiro B. 1993. Varying nutritional dependence of the thyasirid bivalves Thyasira sarsi and T. equalis on chemoautotrophic symbiotic bacteria, demonstrated by isotope ratios of tissue carbon and shell carbonate. Marine Ecology Progress Series 92: 151-158.

Distel D. L. \& Wood A. P. 1992. Characterization of the gill symbiont of Thyasira flexuosa (Thyasiridae: Bivalvia) by use of polymerase chain reaction and $16 \mathrm{~S}$ rRNA sequence analysis. Journal of Bacteriology 174: 6317-6320.

Dufour S. C. \& Felbeck H. 2003. Sulphide mining by the superextensile foot of symbiotic thyasirid bivalves. Nature 426: 65-67.
Friele H. \& Grieg, J. A. 1901. Den Norske Nordhavs-expedition 1876-1878. Zoologi. Mollusca III. Grøndahl \& Søns Bogtrykkeri, Christiania . $131 \mathrm{pp}$.

Iredale T. 1924. Results from Roy Bell's molluscan collections. Proceedings of the Linnean Society of New South Wales 49:179278

Lamarck J. B. P., de. 1818. Histoire Naturelle des Animaux sans Vertèbres, Volume 5. Verdère, Paris: 612 pp.

Linnaeus, C. von. 1758. Systema naturae per regna tria naturae, secundum classes, ordines, genera, species, cum characteribus, differentiis, synonymis, locis: edition 10, Volume 1. L. Salvius, Holmiae. 824 pp.

Oliver P. G. \& Killeen, I. J. 2002. The Thyasiridae (Mollusca: Bivalvia) of the British Continental Shelf and North Sea Oil Fields. An identification manual. Studies in Marine Biodiversity and systematics from the National Museum of Wales. BIOMÔR Reports 3: 1-73.

Payne C. M. \& Allen J. A. 1991. The morphology of deep-sea Thyasiridae (Mollusca, Bivalvia) from the Atlantic Ocean. Philosophical Transactions of the Royal Society of London Series B. 334: 481-562.

Taylor J. D., Williams S. T. \& Glover E. A. 2007. Evolutionary relationships of the bivalve family Thyasiridae (Mollusca: Bivalvia), monophyly and superfamily status. Journal of the Marine Biological Association of the United Kingdom 87: 565-574.

Wood A. P. \& Kelly D. P. 1989. Methylotrophic and autotrophic bacteria isolated from lucinid and thyasirid bivalves containing symbiontic bacteria in their gills. Journal of the Marine Biological Association of the United Kingdom. 69: 165-179.

Zuschin M., Mandic O., Harzhauser M. \& Pervesler P. 2001. Fossil evidence for chemoautotrophic bacterial symbiosis in the thyasirid bivalve Thyasira michelottii from the middle Miocene (Badenium) of Austria. Historical Biology 15: 223-234 